\title{
Petrography and Mineral Chemistry of the Mwenezi-01 Kimberlite, Zimbabwe
}

\author{
Williams, C.M. ${ }^{1}$, Robey, J.v.A. ${ }^{2}$ and Abson, J.P. ${ }^{3}$
}

1. Kimberlitic Searches Limited, 6 Carlisle Street, Belmont, Bulawayo, Zimbabwe.

2. DeBeers Geology Department, Dairy Farm, Wesselton Village, Kimberley, South Africa.

3. Kimberlitic Searches Limited, 6 Carlisle Street, Belmont, Bulawayo, Zimbabwe.

The Mwenezi-01 kimberlite was discovered by Kimberlitic Searches Ltd., in mid-1995. It is located within the Central Zone of the Limpopo Mobile Belt in southern Zimbabwe (Figure 1). It occurs between the previously known River Ranch kimberlite to the southwest and the Shingwizi kimberlite to the northeast. The kimberlite is intruded into Limpopo belt gneisses and is itself intruded by northwest trending dolerites of assumed Karoo ( 180 Ma) age. As the kimberlite has not undergone high-grade metamorphism, the possible age of the kimberlite therefore ranges from $180 \mathrm{Ma}$ to $2000 \mathrm{Ma}$ (the last major metamorphic event in the Central Zone of the Limpopo Belt, Jaeckel et al, 1997).

The kimberlite has been mapped with the use of available outcrop and a regular grid of $25 \mathrm{~m}$ spaced pits, to produce the map shown in Figure 1. Hypabyssal facies macrocrystic kimberlite outcrops in the centre of the pipe. The hypabyssal facies kimberlite is surrounded by poorly exposed crater facies kimberlite. Small slivers of hypabyssal facies kimberlite are found on the southern and western margins of the pipe. The central hypabyssal facies kimberlite and the crater facies kimberlite have been drilled to depths of over $100 \mathrm{~m}$.

Petrographic samples were collected at surface and from drill samples. Hypabyssal facies macrocrystic kimberlite is the dominant hypabyssal facies kimberlite type with subordinate segregationary and flow banded hypabyssal facies kimberlite occurring along the margins of the central and southern hypabyssal facies outcrop (Figure 1). A non-genetic classification scheme, adapted from the one used by Field and Scott Smith (in press), has been used to classify the crater facies rocks. The rocks are classified as either lithic-rich volcaniclastic kimberlite (LVC) or juvenile-rich volcaniclastic kimberlite (JVC), based on the amount of olivine phenocrysts/macrocrysts in the rock ( $\geq 25 \%$ olivine for JVC). The crater facies rocks have been further subdivided based on four textural properties; namely the average clast size (Very Fine, Fine, Medium and Coarse), whether the rock is Matrix or Clast supported, the degree of sorting (Poorly or Well) and the fabric of the rock (Bedded, Massive or Granular). From Table 1 it can be seen that the dominant LVC kimberlite type is VFMWB. The dominant JVC kimberlite type is FMPM. The distribution of the various crater facies kimberlite types is shown in Figure 1. JVC occurs throughout the pipe whereas LVC is restricted to the southern and eastern parts of the pipe. A feature of the petrography of the samples examined is the minimal to severe clinopyroxene alteration that has been observed in the crater and hypabyssal facies rocks. This may be due to deuteric alteration or partial metamorphism at some stage after kimberlite emplacement, possibly related to the Karoo intrusive event.

The heavy mineral concentrates obtained from acidised kimberlite samples contain garnet, spinel ilmenite and clinopyroxene. Garnet parageneses range from lherzolitic to harzburgitic to depleted harzburgitic types (Figure 2). The spinel mineral chemistry shows a significant number of grains plotting in the diamond inclusion field outlined in Figure 3 (Fipke et al, 1995). The concentration of $\mathrm{Ni}$ in the garnets was obtained by means of LA-ICP-MS analysis and used in the formulae published by Ryan et. al. (1996) to obtain pressure and temperature data. These have been plotted on a P-T diagram to determine a geotherm at the time of kimberlite emplacement of $40 \mathrm{~mW} / \mathrm{m}^{2}$ 
(Figure 4). Using this geotherm, most of the garnets have temperatures that fall inside the diamond stability field.

\section{References}

Field, M. and Scott Smith, B.H. (in press) Textural and genetic classification schemes for kimberlites: a new perspective. $7^{\text {th }}$ Int. Kimb. Conf., Cape Town, Extended Abstracts.

Fipke, C.E.. Gurney, J.J., and Moore. R.O.. (1995). Diamond exploration techniques emphasising indicator mineral geochemistry and Canadian examples. Geol. Surv. Canada Bul. 423, 1-86.

Jaeckel, P., Kroner A., Kamo, S.L., Brandle, G., and Wendt, I.J. (1997) Late Archean to early Proterozoic granitoid magmatism and high-grade metamorphism in the central Limpopo belt, South Africa. Journal of the Geological Society, London, 154. 25-44.

Ryan. C.G., Griffin,W.L. and Pearson, N.J. (1996) Garnet geotherms: pressure-temperature data from Cr-Pyrope garnet xenocrysts in volcanic rocks. J. Geophys. Res., 101, 5611-5625.

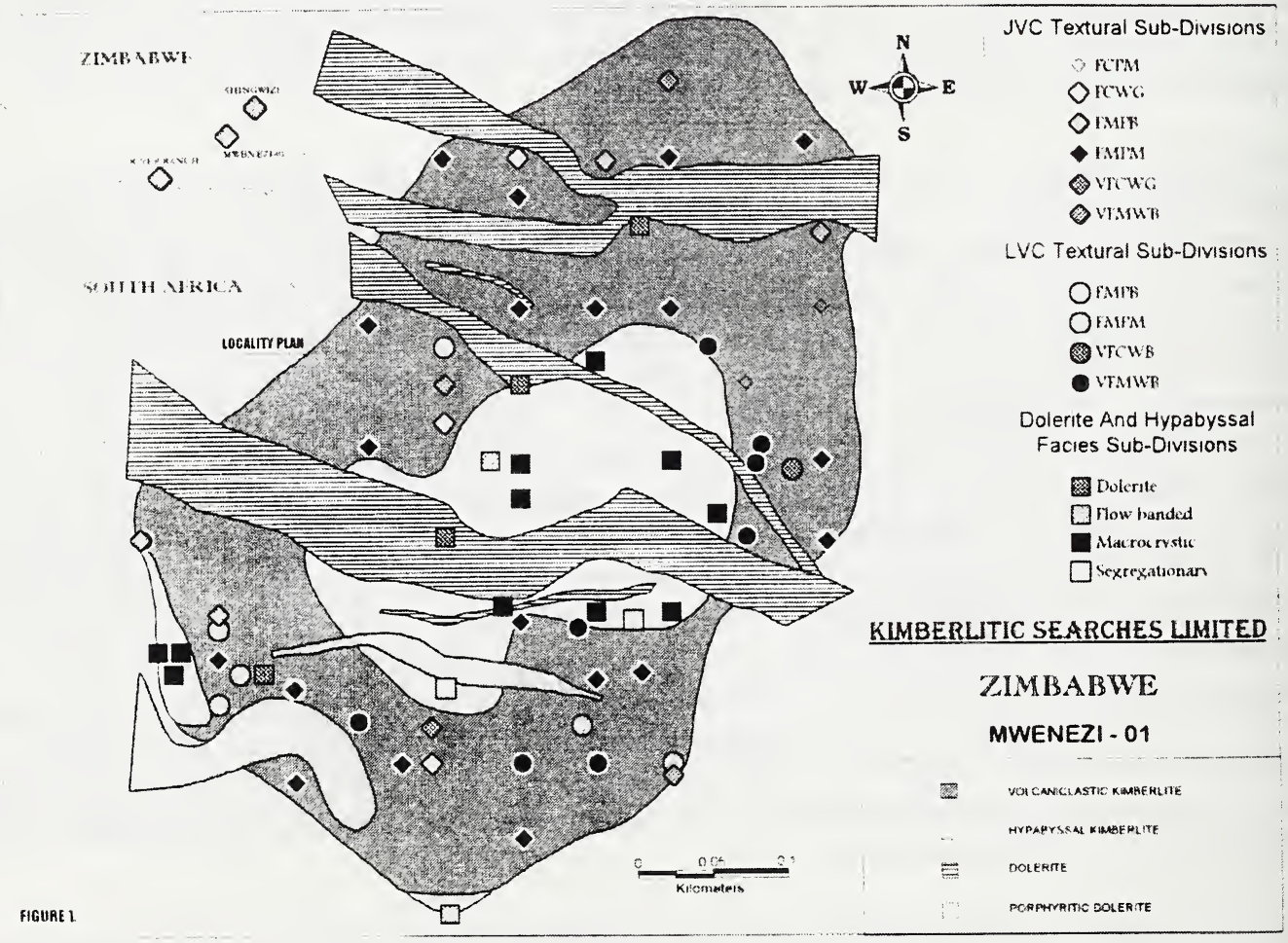



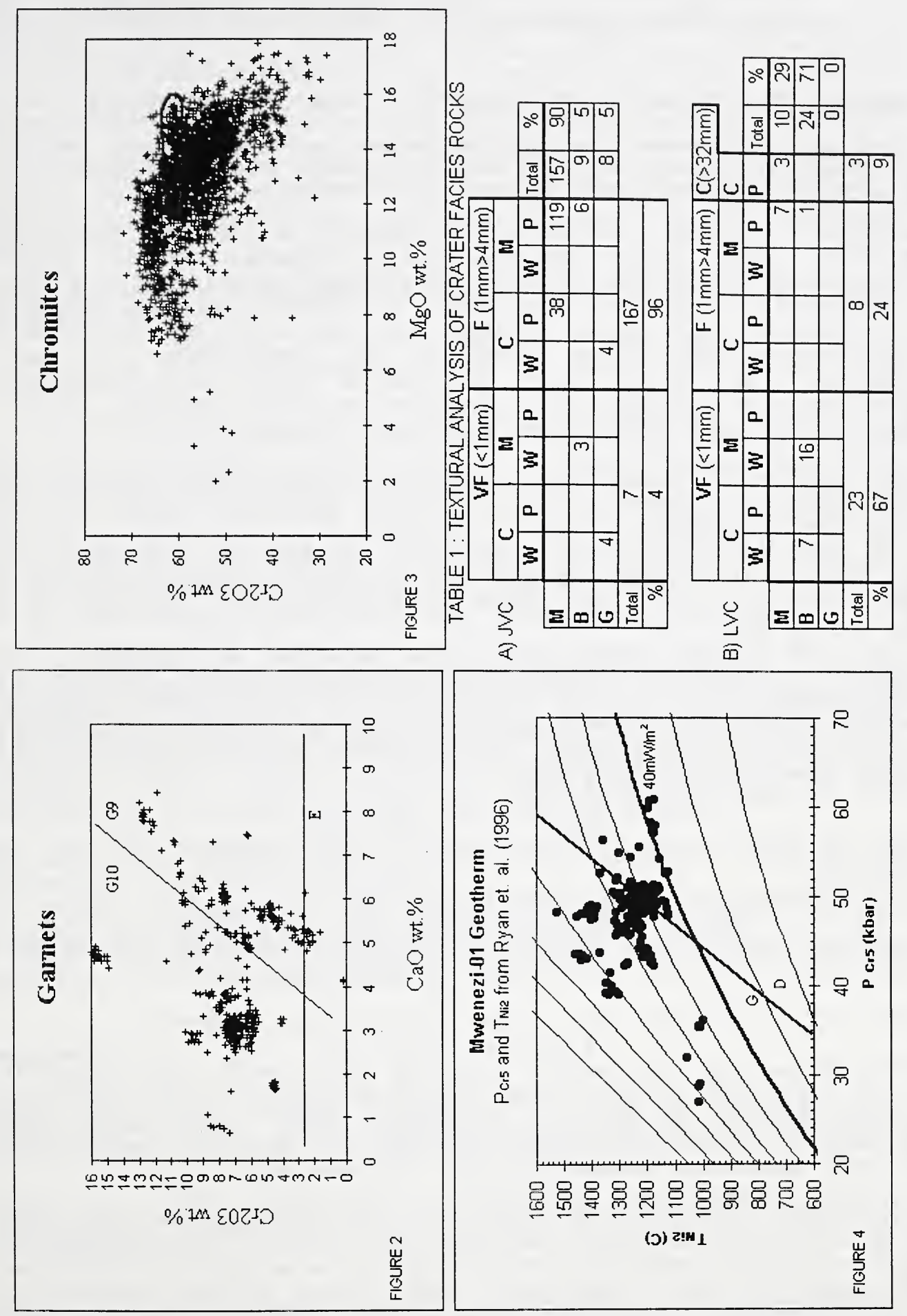